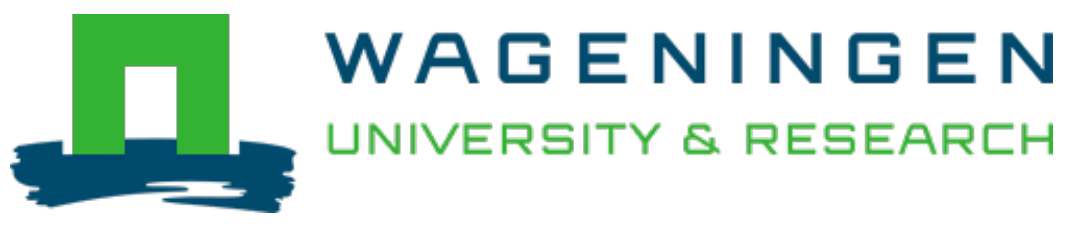

\title{
Spatial quantification to examine the effectiveness of payments for ecosystem services: A case study of Costa Rica's Pago de Servicios Ambientales
}

\author{
Ecological Indicators \\ Havinga, Ilan; Hein, Lars; Vega-Araya, Mauricio; Languillaume, Antoine \\ https://doi.org/10.1016/j.ecolind.2019.105766
}

This article is made publicly available in the institutional repository of Wageningen University and Research, under the terms of article $25 \mathrm{fa}$ of the Dutch Copyright Act, also known as the Amendment Taverne. This has been done with explicit consent by the author.

Article 25 fa states that the author of a short scientific work funded either wholly or partially by Dutch public funds is entitled to make that work publicly available for no consideration following a reasonable period of time after the work was first published, provided that clear reference is made to the source of the first publication of the work.

This publication is distributed under The Association of Universities in the Netherlands (VSNU) 'Article $25 \mathrm{fa}$ implementation' project. In this project research outputs of researchers employed by Dutch Universities that comply with the legal requirements of Article $25 \mathrm{fa}$ of the Dutch Copyright Act are distributed online and free of cost or other barriers in institutional repositories. Research outputs are distributed six months after their first online publication in the original published version and with proper attribution to the source of the original publication.

You are permitted to download and use the publication for personal purposes. All rights remain with the author(s) and / or copyright owner(s) of this work. Any use of the publication or parts of it other than authorised under article $25 \mathrm{fa}$ of the Dutch Copyright act is prohibited. Wageningen University \& Research and the author(s) of this publication shall not be held responsible or liable for any damages resulting from your (re)use of this publication.

For questions regarding the public availability of this article please contact openscience.library@,wur.nl 
Original Articles

\title{
Spatial quantification to examine the effectiveness of payments for ecosystem services: A case study of Costa Rica's Pago de Servicios Ambientales
}

\author{
Ilan Havinga ${ }^{\mathrm{a}, *}$ Lars Hein $^{\mathrm{a}}$, Mauricio Vega-Araya ${ }^{\mathrm{b}}$, Antoine Languillaume ${ }^{\mathrm{c}}$

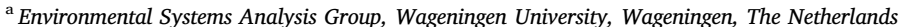 \\ ${ }^{\mathrm{b}}$ Instituto de Investigación y Servicios Forestales, Universidad Nacional, Heredia, Costa Rica \\ ${ }^{\mathrm{c}}$ Biometris, Wageningen University, Wageningen, The Netherlands
}

\section{A R T I C L E I N F O}

\section{Keywords:}

Ecosystem services

Payments for ecosystem services

Conservation

Machine learning

Carbon storage

Ecosystem accounting

\begin{abstract}
A B S T R A C T
Payments for ecosystem services (PES) have been developed as a policy instrument to help safeguard the contributions of ecosystems to human well-being. A critical measure of a programme's effectiveness is whether it is generating an additional supply of ecosystem services (ES). So far, there has been limited analysis of PES programmes based on the actual supply of ES. In line with ecosystem accounting principles, we spatially quantified three ES recognised by Costa Rica's Pago de Servicios Ambientales (PSA) programme: carbon storage, soil erosion control and habitat suitability for biodiversity as a cultural ES. We used the machine learning algorithm random forest to model carbon storage, the Revised Universal Soil Loss Equation (RUSLE) to model soil erosion control and Maxent to model habitat suitability. The additional effect of the PSA programme on carbon storage was examined using linear regression. Forested land was found to store $235.3 \mathrm{Mt}$ of carbon, control for $148 \mathrm{Mt} \mathrm{yr}^{-1}$ of soil erosion and contain 762,891 ha of suitable habitat for three iconic but threatened species. PSA areas enrolled in the programme in both 2011 and 2013 were found to store an additional 9 tonC ha $^{-1}$ on average. As well as enabling a direct quantification of additionality, spatial distribution analysis can help administrators target high-value areas, confirm the conditional supply of ES and support the monetary valuation of ES. Ultimately, this can help improve the social efficiency of payments by enabling a comparison of societal costs and benefits.
\end{abstract}

\section{Introduction}

Human activities are driving a worldwide loss of biodiversity and ecosystems, thereby altering the planet's biogeochemical cycles (Steffen et al., 2015). A lack of compensation of land owners for the biodiversity and ecosystem services (ES) generated on their land is often cited as one of the causes for these losses (Rands et al., 2010; Bullock et al., 2011; Guerry et al., 2015). To counter this, payments for ecosystem (or sometimes, environmental) services (PES) have been developed (Engel et al., 2008; Wunder, 2008; Muradian et al., 2010). One of the world's most established PES schemes is Costa Rica's 'Pago de Servicios Ambientales' (PSA) programme which compensates private land owners for four services produced on their forested land: the mitigation of greenhouse gases, the protection of hydrological sources, biodiversity and scenic beauty (Pagiola, 2008).

A challenge facing the Costa Rican payment system is that there is a lack of information on the societal benefits obtained by the system
(Pagiola, 2008; Porras et al., 2013). There is also no direct quantification of ES in selecting participating areas or examining the effectiveness of the programme. Areas are targeted for specific services but there is generally a lack of data on services and the extent to which the programme is influencing their supply. Studies quantifying ES to examine the effect of the PSA programme are rare (Daniels et al., 2010). Studies that have investigated the impact of the programme have used matching methodologies based on deforestation as a proxy (Daniels et al., 2010; Robalino and Pfaff, 2013). These measurement challenges are common for PES schemes even though measuring the additional amount of ES generated compared to a baseline with no payments is a key measure of a programme's effectiveness (Tacconi, 2012; Börner et al., 2017).

In this context, the System of Environmental Economic Accounting Ecosystem Accounting (SEEA-EA) provides a consistent system to analyse, store and provide easy access to information on ecosystem changes and human implications (UN et al., 2014; Hein et al., 2015). The SEEA

\footnotetext{
* Corresponding author.

E-mail address: ilan.havinga@wur.nl (I. Havinga).
} 


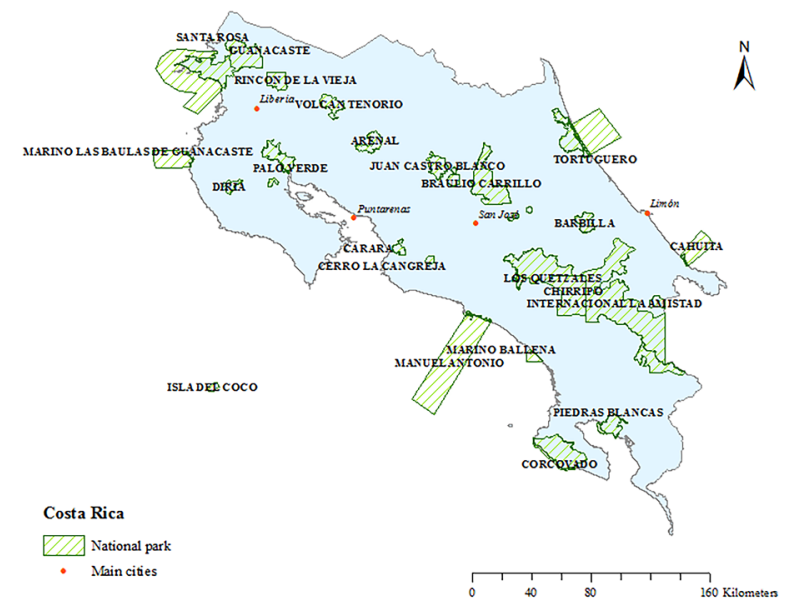

Fig. 1. Map of Costa Rica with its main cities and national park system.

EA framework is part of the United Nations SEEA framework, which is a satellite to the System of National Accounts (SNA), used by almost all countries to produce economic statistics. The SEEA EA considers the exchange value of ES, values that would have been obtained if a market existed for those services, so as to be consistent with the SNA. Monetary evaluation therefore only includes the producer surplus generated in a market and excludes the consumer surplus captured by welfare economics approaches. Elsewhere, outside of ES research, researchers have used innovative machine learning techniques to spatially model environmental variables. For example, the use of the ensemble learning algorithm random forests to model forest biomass (Baccini et al., 2004; Houghton et al., 2007). Similarly, Maxent, a species distribution model based on the principle of maximum entropy, has proven to be a useful approach in the context of ES (Sumarga and Hein, 2014). These techniques, applied using the SEEA EA, promise to provide the spatial detail required at the national level for more effective PES schemes.

The objective of this study is to examine how the spatial quantification of ES can assist PES practitioners determine the effectiveness of a programme, and specifically the Costa Rican PSA programme. Selected ES recognised by the programme are spatially modelled in line with ecosystem accounting principles. These are carbon storage for the mitigation of greenhouse gases, soil erosion control for the protection of hydrological sources, and habitat suitability for biodiversity. We use random forests to model carbon storage, the Revised Universal Soil Loss Equation (RUSLE) for soil erosion control and Maxent to model habitat suitability. We examine the effect of the PSA on carbon storage based on a comparison of sites in a single year (2013) and analyse changes in carbon in areas enrolled between 2011 and 2013. The relevancy of the spatial ES quantities for such an analysis are examined in the discussion. Key innovations in the paper relate to: (i) a combination of ecosystem accounting and PES, including the nation-wide quantification of ES; (ii) the use of machine learning to model ecosystem services; and (iii) a regression analysis of forest conservation policies on ES supply in Costa Rica.

\section{Methods}

\subsection{Study area}

Costa Rica is a country in Central America of 51,100 square kilometres with a rich topography and a tropical to sub-tropical climate. The continental divide has produced two coastal planes divided by a set of large mountain ranges in its middle, reaching a height of $3819 \mathrm{~m}$ (Herrera, 2016). Approximately 52 percent of its area is covered by forest and the country is estimated to have 5 percent of the world's biodiversity (Kappelle, 2016). Costa Rica has a large network of national parks and wildlife reserves, see Fig. 1. The national parks of Costa Rica contain some of the largest continuous stretches of pristine tropical forest in Costa Rica (Boza, 1993).

\subsection{Biophysical spatial ES models}

Three of the ES recognised by the PSA programme in Costa Rica were modelled for the entire forested area of Costa Rica: the mitigation of greenhouse gas emissions, the protection of hydrological sources and biodiversity. ES are defined as the contributions of ecosystems to benefits used in economic and other human activity (UN et al., 2014). Scenic beauty was not modelled due to the challenges in modelling such a service and with the view that biodiversity and scenic beauty are closely aligned (Locatelli et al., 2013). Forested area is defined as primary forest, secondary forest, tree plantations, palm swamp forests and mangrove forests. The PSA programme does not target palm swamp and mangrove forests. However, to gain a more comprehensive overview of ES supply and to allow comparison with other studies, the ES were modelled for all forest types.

The indicators chosen to represent the ES are carbon storage, soil erosion control and habitat suitability for a set of iconic but threatened species. All ES were modelled using data for 2013 unless stated otherwise. The ES were modelled and presented using R 3.4.2, GRASS 7.4. and ArcGIS 10.5. Spatial data in $\mathrm{R}$ was handled using the raster and $\mathrm{sp}$ packages. The data sources are listed in Table 1.

\subsubsection{Carbon storage}

Carbon storage represents an important indicator to measure the mitigation of greenhouse gases as an ES as the majority of Costa Rica's emission reductions are generated through avoided deforestation

Table 1

Modelled ES and source data.

\begin{tabular}{|c|c|c|c|}
\hline ES & Dataset & Dataset type & Source \\
\hline \multirow[t]{4}{*}{ Carbon storage } & Forest inventory plot data & Forestry statistics & Programa REDD/CCAD-GIZ-SINAC (2015) \\
\hline & MODIS Nadir BRDF-Adjusted Reflectance Daily & Raster (500 m resolution) & Schaaf and Wang (2015) \\
\hline & WorldClim 2 climate surfaces & Raster (1 km resolution) & Fick and Hijmans (2017) \\
\hline & Digital elevation model & Raster ( $15 \mathrm{~m}$ resolution) & USGS (2006) \\
\hline \multirow[t]{4}{*}{ Soil erosion control } & TRMM 3B42 3-hourly precipitation records & Raster (0.25 degree resolution) & TRMM (2015) \\
\hline & HWSD soil type and properties & Raster ( $1 \mathrm{~km}$ resolution) and $\mathrm{mdb}$ database file & FAO (2012) \\
\hline & Land cover map & Raster (30 m resolution) & ADUU (2015) \\
\hline & Digital elevation model & Raster (15 m resolution) & USGS (2006) \\
\hline \multirow[t]{5}{*}{ Habitat suitability } & GBIF species presence data & $\mathrm{R}$ dataframe with coordinates & GBIF (2017) \\
\hline & WorldClim 2 climate surfaces & Raster (1 km resolution) & Fick and Hijmans (2017) \\
\hline & MODIS Vegetation Continuous Fields Yearly & Raster (250 m resolution) & Dimiceli et al. (2015) \\
\hline & Land cover map & Raster (30 m resolution) & ADUU (2015) \\
\hline & Digital elevation model & Raster (15 m resolution) & USGS (2006) \\
\hline
\end{tabular}


(Pagiola, 2008). Carbon storage was modelled using the machine learning algorithm random forests developed by Breiman (2001). Random forests is an ensemble learning method for regression which uses decision trees and bootstrap sampling techniques to generate a mean prediction for a response variable using a set of predictor variables. Tree-based models have been applied in a number of studies to map aboveground biomass and carbon storage using remote sensing and forest inventory data (Baccini et al., 2004, 2008; Houghton et al., 2007; Saatchi et al., 2007; Yin et al., 2015).

The ranger package in $\mathrm{R}$ was used to build the random forests model (Wright and Ziegler, 2017). This was implemented within the wrapper package caret (Kuhn, 2008). caret was set to automatically select the best maximum number of predictor variables available at each split within each tree, termed 'mtry', and whether to randomly choose predictors at each tree node, referred to as "extratrees", or the locally optimal number of predictor variables based on the variance of the responses, termed 'variance'. The number of trees permitted to grow in each of the models was set to 100 .

The model was trained on forest inventory data from 2014 using a variety of remote-sensing, climatic and topographical predictor variables. 155 plot measurements in the forest inventory were used after removing plots with issues related to location or observed vegetation (see Appendix A). The total estimated carbon per hectare for each plot was taken and geo-located using the plot coordinates.

The predictor variables were selected using a pre-screening approach that utilised the Boruta package in R (Appendix A). Table 2 lists the variables. The first dataset used was the Moderate-resolution Imaging Spectroradiometer (MODIS) Nadir BRDF-Adjusted Reflectance Daily product (MOD34A4.V6) at $500 \mathrm{~m}$ resolution (Schaaf and Wang, 2015). This product provides a repeated 16-day composite of observations that have been cloud-screened and corrected for atmospheric haze and aerosols (Schaaf et al., 2002). The Normalised Difference Moisture Index (NDMI) using the MODIS reflectance bands was also used. NDMI is sensitive to the moisture content of vegetation and has been used to detect different stand ages of vegetation (Jin and Sader, 2005). NDMI is calculated as:

$N D M I=\frac{(N I R-S W I R 1)}{(N I R+S W I R 1)}$

where NIR refers to the near infrared band of the satellite at $0.841-0.876 \mu \mathrm{m}$ and $S W I R 1$ to the shortwave infrared band at $1.628-1.654 \mu \mathrm{m}$.

Landsat reflectance bands were also tested as predictor variables. At $30 \mathrm{~m}$ resolution, the imagery improved the spatial variation of the model outputs. However, cloud cover presents a serious challenge in Costa Rica; no fully cloud-free pixels were available for many areas during the entire year. The reflectance bands also did not improve the predictive power of the model over that of the bioclimatic variables.

Elevation and bioclimatic variables from the WorldClim 2 climate surfaces were also identified as strong predictors. The WorldClim 2 climate surfaces have been calculated by spatially interpolating satellite and weather station data (Fick and Hijmans, 2017). Within this set, the temperature annual range $\left({ }^{\circ} \mathrm{C}\right)$, annual precipitation $(\mathrm{mm})$ and precipitation of the driest quarter $(\mathrm{mm})$ were used.

To assess the overall predictive strength of the model, a repeated cross-validation approach was taken. The data was randomly split into 50 groups with one group held out repeatedly as the validation dataset and the others used to train the model. This procedure was repeated 50 times and the results averaged. $\mathrm{R}^{2}$ and Root Mean Squared Error (RMSE) was used as metrics to measure model performance. $\mathrm{R}^{2}$ reflects the variance in the response variable explained by the model across the validation datasets while RMSE is a measure of error between observed and predicted values (Kuhn and Johnson, 2013). Predictor variable importance was measured using the node impurity statistic. In the case of regression, this shows the decrease in variance in the estimated response of the dependent variable (carbon storage) as a result of a decision node splitting on a predictor variable. The node impurities per predictor variable were summed across all trees and scaled to have a maximum value of 100 .

\subsubsection{Soil erosion control}

The PSA programme recognises the hydrological services forests provide for the protection of drinking water and production of hydroelectric energy (Porras et al., 2013). Water quality is a primary concern in Costa Rica (Pagiola, 2008). Vegetation plays a key role in reducing soil erosion and sediment run-off into water bodies. High sediment loads affect drinking water quality, water for irrigation and hydroelectric power generation (Locatelli et al., 2013). For these reasons, soil erosion control provides a good indicator to measure this service. The difference between soil loss on each land cover unit and on bare soil can be used to represent the additional soil erosion control provided by the vegetation cover of each unit.

The Revised Universal Soil Loss Equation (RUSLE) was used to model soil erosion control. RUSLE was developed in the United States by Renard et al., (1997) and has been used to measure soil loss at the national and watershed scale in a number of different tropical countries including Costa Rica (Angima et al., 2003; Batista et al., 2017; Hoyos, 2005; Locatelli et al., 2013; Rubin and Hyman, 2000). It offers a straightforward approach to calculating soil erosion rates, requiring a relatively small amount of input data and good compatibility with Geographic Information Systems (GIS) (Millward and Mersey, 1999).

To calculate soil erosion control, soil loss was first calculated for all eligible forested land excluding palm swamp and mangrove forests as soil erosion is not relevant to these types of ecosystems. This meant the calculations were restricted to primary forest, secondary forest and tree plantations. Soil loss was then calculated for these same areas as bare soil and the difference taken to represent the soil erosion control delivered by the vegetation. Soil loss was calculated as follows:

$A=R \cdot K \cdot L S \cdot C \cdot P$

with $A$ expressed in ton $\mathrm{ha}^{-1} \mathrm{yr}^{-1}$ representing the annual soil loss

Table 2

Carbon storage predictor variables.

\begin{tabular}{ll}
\hline Dataset & Predictor variable \\
\hline MODIS Nadir BRDF-Adjusted Reflectance Daily & Band 1 - blue $(0.459-0.479 \mu \mathrm{m})$ \\
& Band 3 - red $(0.620-0.670 \mu \mathrm{m})$ \\
& Band 4 - near-infrared $(0.841-0.876 \mu \mathrm{m})$ \\
& Band 5 - short-wave infrared $(1.230-1.250 \mu \mathrm{m})$ \\
& Band 6 - short-wave infrared $(1.628-1.654 \mu \mathrm{m})$ \\
& Band 7 - short-wave infrared $(2.105-2.155 \mu \mathrm{m})$ \\
WorldClim 2 climate surfaces & NDMI - normalised difference moisture index \\
& Bio7 - Temperature annual range $\left({ }^{\circ} \mathrm{C}\right)$ \\
Digital elevation model & Bio12 - Annual precipitation $(\mathrm{mm})$ \\
& Bio17 - Precipitation of the driest quarter $(\mathrm{mm})$ \\
& Elevation (m) \\
\end{tabular}




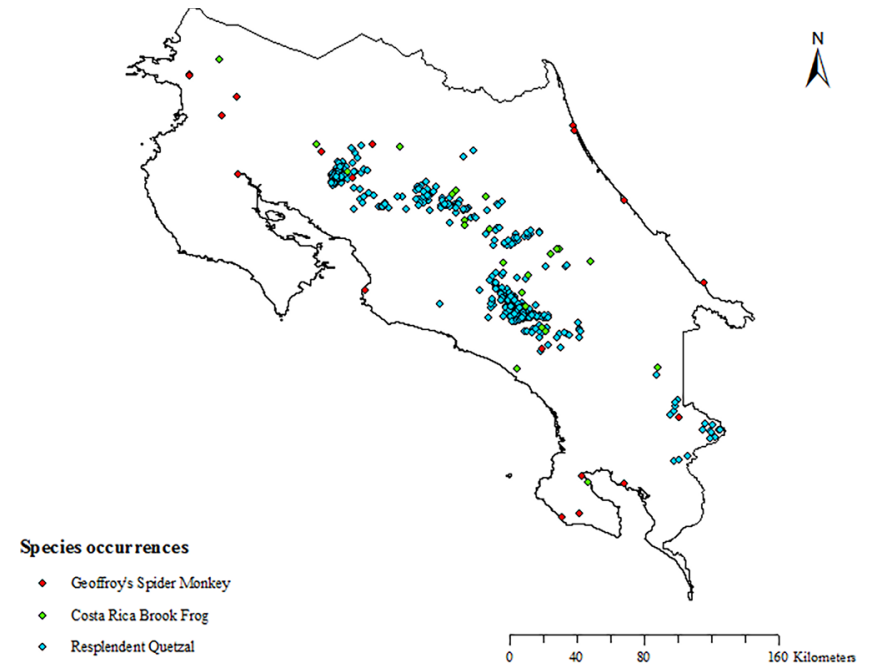

Fig. 2. Modelled species occurrence records.

rate, $R$ the rainfall erosivity factor ( $\mathrm{MJ} \mathrm{mm} \mathrm{ha}{ }^{-1} \mathrm{~h}^{-1} \mathrm{yr}^{-1}$ ), $K$ the soil erodibility factor (ton ha h $\mathrm{ha}^{-1} \mathrm{MJ}^{-1} \mathrm{~mm}^{-1}$ ), $L S$ the slope length and steepness factor (dimensionless), $C$ the land cover management factor (dimensionless) and $P$ the support practice factor (dimensionless). The support practice function describes any implemented measures that reduce the potential of run-off. For the purposes of this study, $P$ was set to 1 due to its relevance only to managed crops and the absence of calculated factors for tree plantations. Please refer to Appendix B for detailed calculations concerning each factor.

\subsubsection{Habitat suitability}

Costa Rica has one of the greatest concentrations of biodiversity in the world and ecotourism is one of the cornerstones of its economy because of the unique biodiversity the country offers (Hearne and Salinas, 2002). A key funding target for the PSA programme has been the tourism industry because of the benefits it gains from the biodiversity in the country (Pagiola, 2008). When considering the value of wildlife-related activities such as ecotourism, measures of biodiversity are indicators of cultural ES (UN, 2017). Mapping the suitable habitat for a set of unique but threatened "flagship" species can therefore represent an indicative ES flow generated by the biodiversity of most cultural interest to the country. These species can act as rallying points for the conservation of biodiversity and their suitable habitat include habitat for a wider range of biodiversity (Caro et al., 2004).

Three species from different taxonomical groups were chosen to model habitat suitability. These species have strict requirements on habitat quality including absence of disturbance, and protecting these species will therefore also contribute to conserving other species in Costa Rica. However, we acknowledge that three species are not representative of Costa Rica's complex biodiversity and emphasise that we measure this service as a cultural ES. We return to this in the discussion. The three species are the Resplendent Quetzal (Pharomachrus mocinno), found only between southern Mexico and western Panama (Wheelwright, 2016) and dubbed "the most spectacular bird in the New World" (Peterson and Chalif, 1973), the Costa Rica Brook Frog (Duellmanohyla uranochroa), only recently re-discovered and a focus for amphibian conservation in the country (Garcia-Rodriguez et al., 2012), and finally Geoffroy's Spider Monkey (Ateles geoffroyi) which holds an iconic status within Costa Rica's ecotourism industry (Graham et al., 2013). All these species are listed as either Endangered or Near Threatened on the IUCN Red List (IUCN, 2015).

To model habitat suitability, the Maxent species distribution modelling tool was chosen which is based on the principle of maximum entropy. It uses occurrence data of a selected species and a set of environmental predictors to model its probable distribution within a study area, subject to the constraints of the predicator variables (Phillips et al., 2006). A location with a probability of 0.632 can be considered typical for the species (Phillips et al., 2017). Occurrence data was sourced from the Global Biodiversity Information Facility (GBIF) and downloaded using the rgbif R package (Chamberlain, 2017), filtered to exclude records with any geospatial issues or points that were outside the country's administrative area. In total, 6537 occurrences records were sourced for the Resplendent Quetzal, 84 for the Costa Rican Brook Frog and 28 for Geoffroy's Spider Monkey. A list of the species, the GBIF dataset source and the number of occurrences used from each dataset is given in Appendix C.

The environmental predictors used to model the three species were elevation, percentage tree cover, accessible forest area and a reduced selection of the WorldClim climate surfaces: annual mean temperature, temperature annual range and precipitation of the driest quarter (Fick and Hijmans, 2017). These climate surfaces were selected after a check for multicollinearity. Percentage tree cover was sourced from the MODIS Vegetation Continuous Fields Yearly product (MOD44B.V6) at a $250 \mathrm{~m}$ resolution (Dimiceli et al., 2015). Accessible forest area was calculated for the Brook Frog because amphibian species are particularly sensitive to forest fragmentation, preferring continuous forest (Bell and Donnelly, 2006). It gives the area of primary forest accessible within a $300 \mathrm{~m}$ distance of each grid cell; a range based on a more common amphibian species, the Red-Eyed Tree Frog (Agalychnis callidryas) (Bell and Donnelly, 2006).

Two sub-sampling methods were employed in order to try to remove spatial bias and improve model performance. The first method was to grid sample the species presence points where the number of occurrences allowed it. This reduces the spatial aggregation of presences by sampling only one point within a specific distance (Fourcade et al., 2014). For the Resplendent Quetzal, a sampling grid of $1 \mathrm{~km}$ was applied, reducing the number of presences to 343 . Fig. 2 shows the species occurrences used for modelling. The second method was to use targetgroup background point sampling which uses occurrence data of a species' taxonomical group to help the model differentiate between suitable areas (Phillips et al., 2009). This resulted in 4078 background points for the Resplendent Quetzal, 2367 for the Costa Rica Brook Frog and 2147 for Geoffroy's Spider Monkey.

Model accuracy was reviewed using the area under the curve (AUC) statistic. The AUC is generated by a receiver operating characteristic (ROC) curve which in the case of Maxent reflects the ability of the model to predict presence from random using a set of presence and background points (Phillips et al., 2006). The total forested area with distribution values equal to or higher than 0.632 were then taken as the area of suitable habitat for each of the species.

\subsection{Exploring the effect of the PSA programme on the supply of carbon storage}

\subsubsection{Single-year analysis}

To gauge the effect of the PSA programme on ES supply in a single year, a linear regression was performed on the supply of carbon storage in 2013, correcting for several other anthropogenic factors. Carbon storage was chosen as an ES due to its importance to the policy-objectives of the programme (Porras et al., 2013). The R packages stats and emmeans were used to perform the regression. Spatial analysis was conducted using the raster and rgeos packages.

To produce observations for the model, 400 points were randomly generated inside PSA areas, eligible areas not enrolled in the programme (primary forest, secondary forest and tree plantations) and national parks. In total, this produced 1200 points. Eq. (3.3) gives the regression model equation. Let $\mathrm{y}_{\mathrm{ij}}$ be the amount of carbon stored (ton $\mathrm{ha}^{-1}$ ) for policy $i$ at point $j$.

$y_{i j}=\mu+\beta_{\text {policy }} P_{i}+\beta_{\text {slope }} S_{i j}+\beta_{\text {road }} R_{i j}+\beta_{\text {pop }} P o_{i j}+\varepsilon_{i j}$

The equation shows the line intercept $\mu$ and the residual error term 
$\varepsilon_{i j} \tilde{\mathrm{N}}\left(0, \sigma^{2}\right)$ which was assumed to be normally distributed with mean 0 and variance $\sigma^{2}$. The PSA programme was incorporated into a categorical predictor variable $\left(P_{i}\right)$ indicating whether an area was under contract, in an eligible area or national park. This allowed comparison with areas outside the programme as well as the national park system of Costa Rica as an alternative conservation policy. A map of PSA areas was provided by the Fondo Nacional de Financiamiento Forestal (FONAFIFO, 2018) and the national park system in 2014 from the Instituto de Investigación y Servicios Forestales, Universidad Nacional, Heredia.

Slope $\left(S_{i j}\right)$, distance to the nearest road $\left(R_{i j}\right)$ and distance to the nearest population area $\left(\mathrm{Po}_{i j}\right)$ were added to the model as covariates to correct for other key anthropogenic influences on ES supply. Slope was chosen to reflect the strong influence it has on the agricultural potential of land (Ferraro et al., 2011). It was calculated using the available $15 \mathrm{~m}$ digital elevation model. Distance to the nearest road and population area were chosen as covariates to reflect population pressure. Spatial files were available through the Instituto de Investigación y Servicios Forestales. Human populations in the tropics commonly lead to deforestation and loss of habitat in surrounding areas (Defries et al., 2010). The resulting road networks lead to habitat fragmentation and further deforestation by increasing the accessibility of the area (Laurance et al., 2009).

For comparison purposes, each covariate was scaled by subtracting values with the mean and dividing by the standard deviation. To determine whether the difference in carbon stored between policy types was significant, pairwise comparison was performed between the adjusted means of the categorical variable policy $\left(P_{i}\right)$ using a Tukey Test.

\subsubsection{Short-term trend analysis}

A short-term trend analysis between 2011 and 2013 was also conducted to explore the effect of the programme over time. This timeframe was chosen based on the data available to us. We return to this in the discussion. First, carbon storage was modelled for 2011 using the random forests model created in Section 2.2.1 and MOD34A4.V6 reflectance bands sourced for 2011. The single-year regression analysis was then repeated, incorporating the year as an additional predictor variable. In this case, only PSA areas existing in both 2011 and 2013 were sampled to be able to gauge the effect of the programme over time. The model is shown in Eq. (3.4) with year as the additional predictor which is denoted by $Y_{k}$, the effect of the year $k$. The error term, $\varepsilon_{i j k} \tilde{\mathrm{N}}\left(0, \sigma^{2}\right)$ followed the same assumptions as model Eq. (3.3).

$y_{i j k}=\mu+\beta_{\text {policy }} P_{i}+\beta_{\text {slope }} S_{i j}+\beta_{\text {road }} R_{i j}+\beta_{\text {pop }} P o_{i j}+\beta_{\text {year }} Y_{k}+\varepsilon_{i j k}$

Observations for the model were generated by randomly generating 400 points in 2011-2013 PSA areas, eligible areas existing outside the PSA programme in 2011 and within national parks. These 1200 points were then used to sample carbon and the predictor values in 2011 and 2013. All predictors were scaled and the PSA effect examined using the adjusted means. Once again, pairwise comparisons among policy means were carried out using a Tukey Test.

In addition to this analysis, a third model (Eq. (3.5)) with an added interaction term between year and policy was considered to assess whether the policy effect changed between years. To determine the significance of the interaction term, a F-test was carried out using model Eq. (3.4) as the null model.

$y_{i j k}=\mu+\beta_{\text {policy }} P_{i}+\beta_{\text {slope }} S_{i j}+\beta_{\text {road }} R_{i j}+\beta_{\text {pop }} P o_{i j}+\beta_{\text {year }} Y_{k}+\beta_{\text {policy } * \text { year }} P_{i} Y_{k}+\varepsilon_{i j k}$

\section{Results}

\subsection{Biophysical spatial ES}

\subsubsection{Carbon storage}

The most accurate random forest model chosen by the caret package employed 'variance' as a split rule with a maximum of 11 predictor
Carb on storage (ton ha-1)

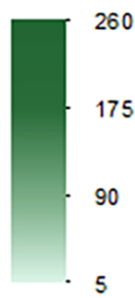

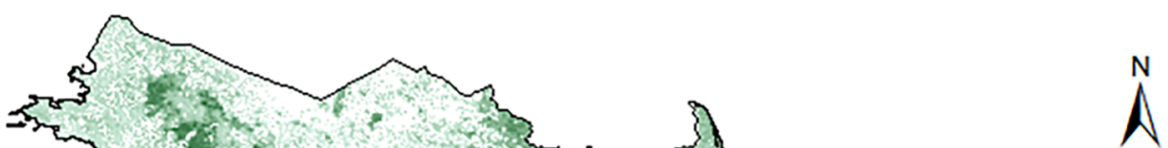
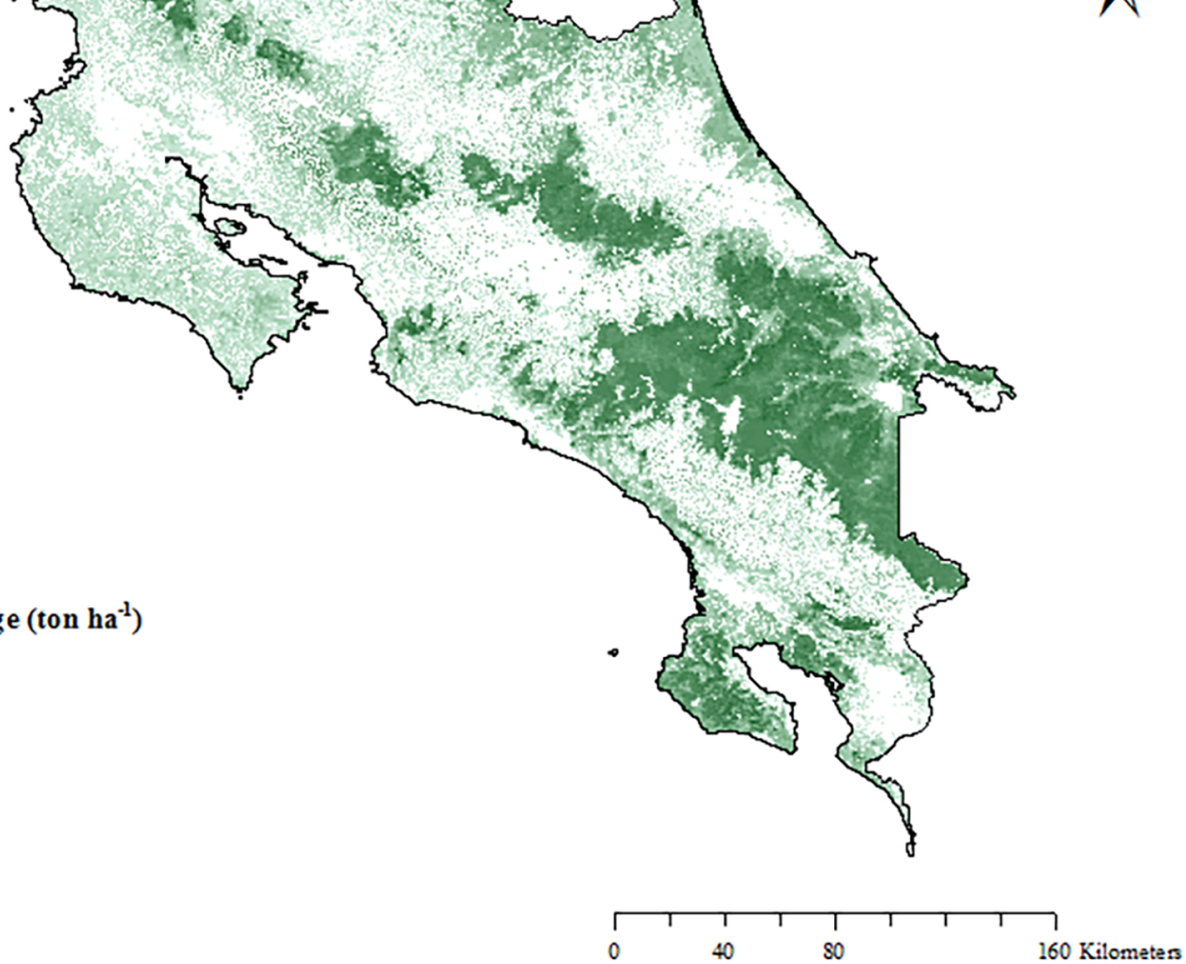

Fig. 3. Estimated carbon storage for all forested land in Costa Rica (ton ha ${ }^{-1}$ ). 
Table 3

Carbon storage.

\begin{tabular}{|c|c|c|c|c|c|c|}
\hline Land cover & $\operatorname{Min}\left(\right.$ ton $\mathrm{ha}^{-1}$ ) & Median (ton ha ${ }^{-1}$ ) & Mean (ton ha ${ }^{-1}$ ) & Max (ton ha ${ }^{-1}$ ) & Total area (m ha) & Total carbon (Mt) \\
\hline Primary forest & 6.0 & 78.9 & 87.4 & 262.3 & 2.2 & 189.3 \\
\hline Secondary forest & 6.1 & 42.2 & 49.0 & 253.6 & 0.6 & 28.8 \\
\hline Tree plantations & 5.6 & 36.4 & 38.5 & 238.9 & 0.2 & 6.4 \\
\hline Palm swamp forest & 6.4 & 55.6 & 59.2 & 188.2 & 0.1 & 8.0 \\
\hline Mangrove forest & 9.0 & 55.3 & 57.5 & 201.3 & 0.05 & 2.8 \\
\hline Overall & 5.6 & 57.0 & 75.8 & 262.3 & 3.1 & 235.3 \\
\hline
\end{tabular}

variables available per split (mtry). The chosen model had a $\mathrm{R}^{2}$ of 0.63 and a RMSE of 46.9 ton $\mathrm{ha}^{-1}$. In general, the model overestimated carbon at the forest inventory plots although it underestimated carbon at the forest inventory plots with very large recorded concentrations. This underestimation is a common limitation to modelling biomass from satellite observations (Gibbs et al., 2007). The predictor variable of most importance was MODIS band 3 with a scaled reduction in variance of 100 . This was followed by MODIS band 4 with a score of 49 . Band 4 was followed by band 1 at 36, band 6 at 35 and band 7 at 23. MODIS-NDMI achieved a score of 22 . All other predictors scored below 10 .

Fig. 3 shows the distribution of carbon across Costa Rica. A large concentration of carbon lies in the south of the country along the central mountain ranges. This falls within the protected areas of Chirripo National Park and La Amistad International Park. Here, carbon stored in the aboveground vegetation regularly reaches 150 ton ha ${ }^{-1}$. Moving towards the Caribbean coast, there is also a large amount of carbon stored in the forests of the lowland areas, reaching over 200 ton ha $^{-1}$ in some places. The Osa Pensinsula in the southwest of the country on the Pacific also shows large concentrations of carbon, generally between 100 and 150 tonC $\mathrm{ha}^{-1}$.
Table 3 gives the carbon storage per forest type. In total, 235.3 Mt of carbon were estimated for all forested land in Costa Rica. Primary forest was estimated to store a total of 189.3 megatons (Mt) of carbon with an average 87.4 tonC ha $^{-1}$ and median of 78.9 tonC $^{-1}$, the largest out of all three forest types. Secondary forests were estimated to store $28.8 \mathrm{Mt}$ with an average of 49.0 tonC $\mathrm{ha}^{-1}$ and median of $42.2 \mathrm{tonC} \mathrm{ha}^{-1}$. Tree plantations stored on average $38.5 \mathrm{tonC} \mathrm{ha}^{-1}$, with a median of 36.4 tonC ha ${ }^{-1}$ and 6.4 Mt in total. Palm swamp forest was found to store $8.0 \mathrm{Mt}$ carbon, an average of $59.2 \mathrm{tonCha}^{-1}$ and median of 55.6 tonC $\mathrm{ha}^{-1}$, while mangroves, which cover a much smaller area, stored $2.8 \mathrm{Mt}$ in total, 57.5 tonC $^{-1}$ on average and had a median value of 55.3 tonC $\mathrm{ha}^{-1}$. Analysing the minimum and maximum figures for each forest type, the amount of carbon storage is fairly similar, excluding palm swamp and mangrove forest which store a smaller range.

\subsubsection{Soil erosion control}

Calculating soil erosion control using the RUSLE model produced a mostly uniform distribution of soil erosion across the country although sharp increases occur in the more mountainous areas (Fig. 4). This uniformity is reflected in the median values for primary and secondary

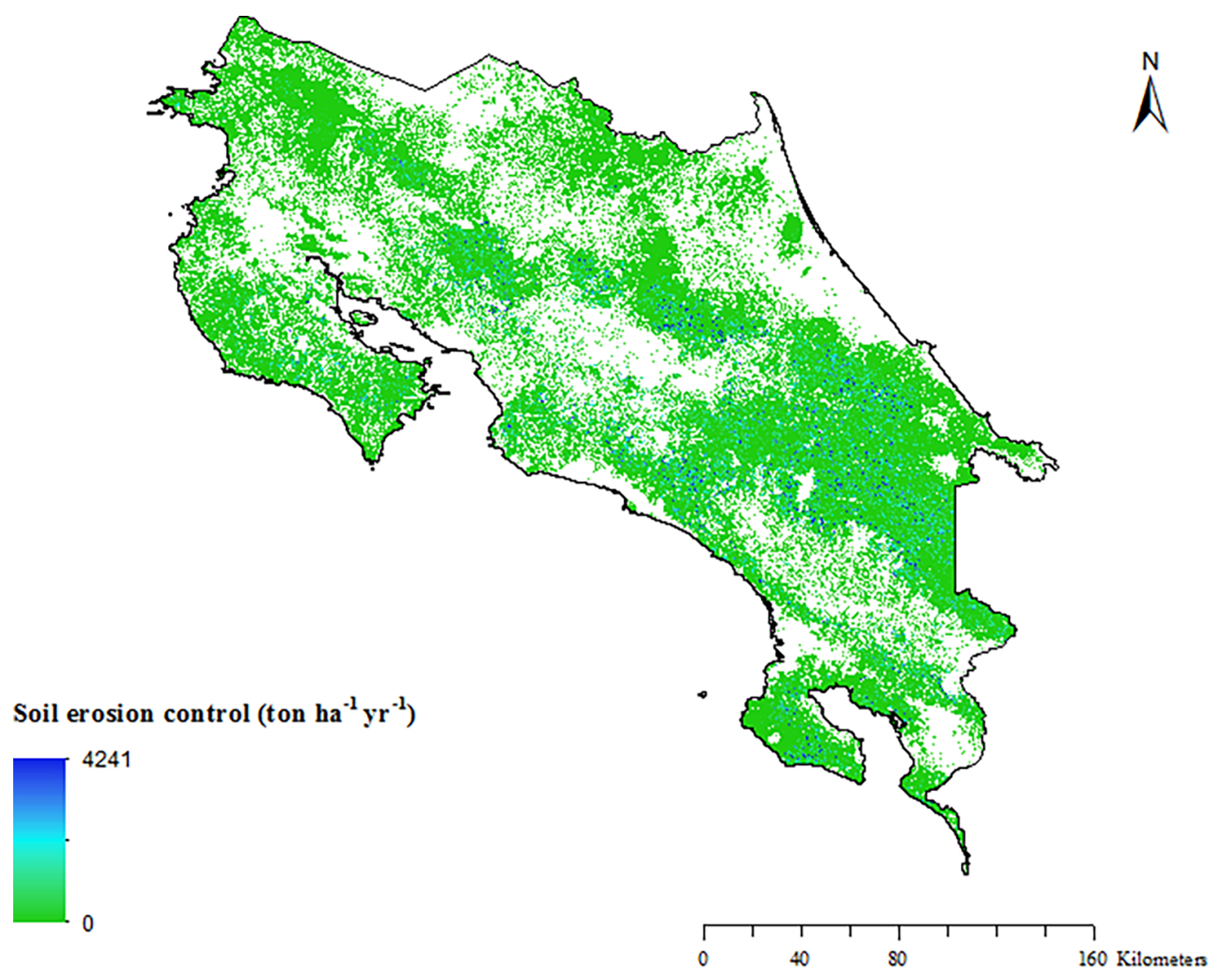

Fig. 4. Soil erosion control (ton $\mathrm{ha}^{-1} \mathrm{yr}^{-1}$ ). 
Table 4

Soil erosion control.

\begin{tabular}{|c|c|c|c|c|c|c|}
\hline Land cover & $\operatorname{Min}\left(\right.$ ton $\mathrm{ha}^{-1} \mathrm{yr}^{-1}$ ) & Median (ton $\mathrm{ha}^{-1} \mathrm{yr}^{-1}$ ) & Mean (ton $\mathrm{ha}^{-1} \mathrm{yr}^{-1}$ ) & Max (ton $\mathrm{ha}^{-1} \mathrm{yr}^{-1}$ ) & Total area (m ha) & Total $\left(\mathrm{Mt} \mathrm{yr}^{-1}\right)$ \\
\hline Primary forest & 0.27 & 1.2 & 60 & 4241 & 2.2 & 130 \\
\hline Secondary forest & 0.27 & 1.1 & 28 & 4072 & 0.6 & 16 \\
\hline Tree plantations & 0.24 & 9.1 & 10 & 1428 & 0.2 & 2 \\
\hline Overall & 0.24 & 1.3 & 51 & 4241 & 2.9 & 148 \\
\hline
\end{tabular}

forest (Table 4). The areas with lowest soil erosion control are in the northern lowlands and in the north-western province of Guanacaste with control levels between 0 and 16 ton ha ${ }^{-1} \mathrm{yr}^{-1}$ compared to bare soil. The areas which contributed the most were in the central mountain ranges where the steep slopes would mean the absence of vegetation cover would greatly increase soil erosion rates. Here, rates range from the very low, between 0 and 77, to high control rates of up to 381 ton $\mathrm{ha}^{-1} \mathrm{yr}^{-1}$, and in some rare cases over 2000 ton $\mathrm{ha}^{-1} \mathrm{yr}^{-1}$.

Overall, primary forest contributed the most with an average soil erosion control rate of 60 ton ha ${ }^{-1}$, a maximum control rate of 4241 ton $\mathrm{ha}^{-1} \mathrm{yr}^{-1}$, and in total controlled for almost $130 \mathrm{Mt} \mathrm{yr}^{-1}$ of soil erosion. This was followed by secondary forest which had an average soil erosion control rate of $28 \mathrm{ton}^{-1} \mathrm{ha}^{-1} \mathrm{yr}^{-1}$, a maximum control rate of $4072 \mathrm{ton}^{-1} \mathrm{ha}^{-1} \mathrm{yr}^{-1}$, and in total controlled for $16 \mathrm{Mt} \mathrm{yr}^{-1}$ of soil erosion. Tree plantations contributed the least out of the three forest types, having an average control rate of
10 ton $^{-1} \mathrm{ha}^{-1} \mathrm{yr}^{-1}$, a maximum control rate of 1428 ton $^{-1} \mathrm{ha}^{-1} \mathrm{yr}^{-1}$, and controlled for $2 \mathrm{Mt} \mathrm{yr}^{-1}$ of soil. Nonetheless, the median control rate was much higher than the other forest types, reflecting a more consistent provision of ES supply across the area covered. Overall, the minimum amount of soil erosion control within each forest type was very similar.

\subsubsection{Habitat suitability}

The models generated for each of the three species all showed a good predictive ability. The model accuracy for the Brook Frog was the highest out of all the species with an AUC of 0.95. This was followed by the Resplendent Quetzal model with 0.90 and the model for Geoffroy's Spider Monkey at 0.86 . More information on the models including predictor variable importance can be found in Appendix C.

The distribution of suitable habitats is shown in Fig. 5. In total, 762,891 ha of suitable habitat was predicted for all forested area in

\section{Suitable habitat}

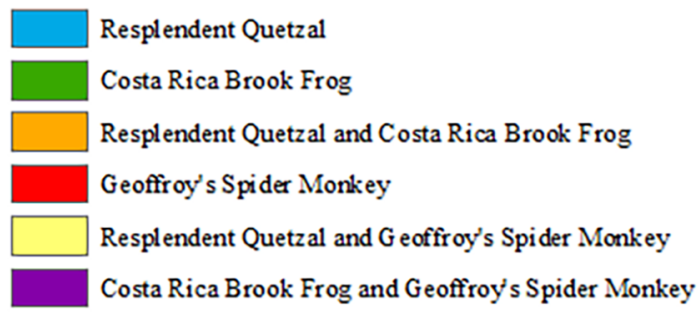

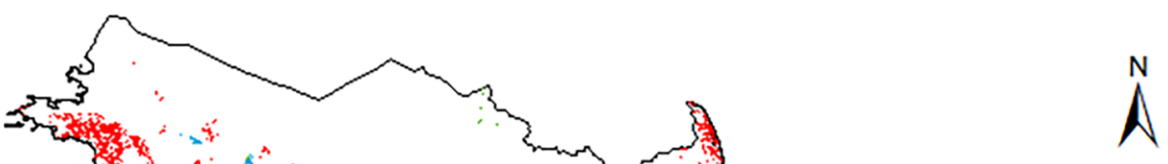
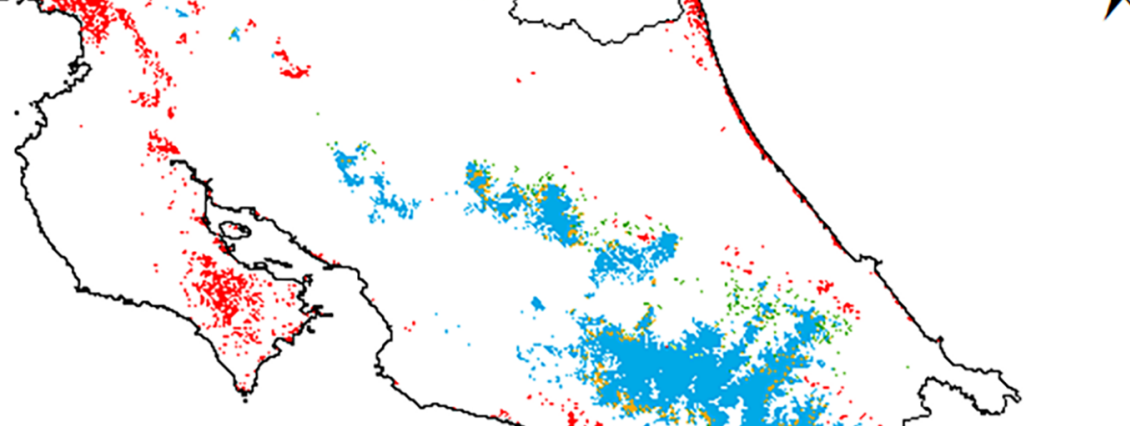

Fig. 5. Overall habitat suitability for the Resplendent Quetzal, Costa Rica Brook Frog and Geoffroy's Spider Monkey. 
Table 5

Total areas of suitable habitat.

\begin{tabular}{ll}
\hline Area of suitability & Total area (ha) \\
\hline Resplendent Quetzal (Pharomachrus mocinno) & 490,019 \\
Costa Rica Brook Frog (Duellmanohyla uranochroa) & 49,699 \\
Geoffroy's Spider Monkey (Ateles geoffroyi) & 189,730 \\
Area suitable for two species & 33,443 \\
Total area of suitable habitat & 762,891 \\
\hline
\end{tabular}

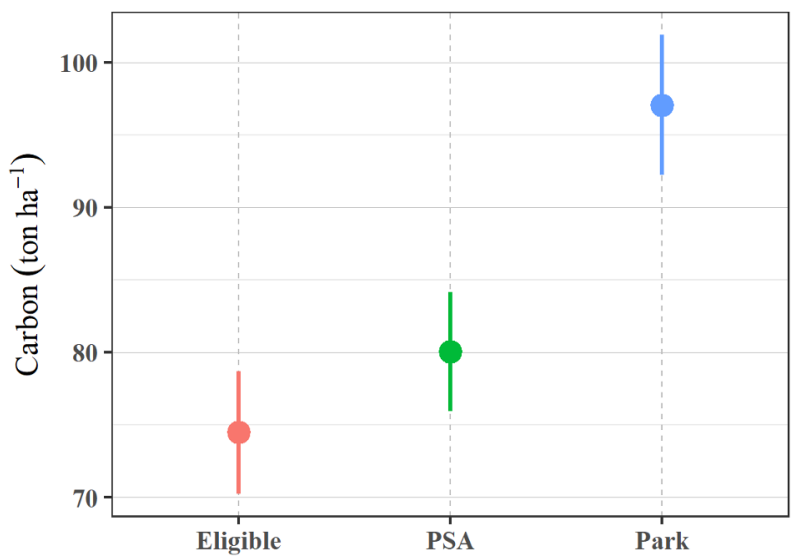

Fig. 6. Adjusted means for carbon storage (ton ha ${ }^{-1}$ ) per policy type. The points represent the mean carbon stored (ton ha ${ }^{-1}$ ), adjusted for the covariates road, slope and population, while the bars represent the $95 \%$ confidence intervals for each of the means. The model had an $\mathrm{R}^{2}$ of 0.42 .

Costa Rica (Table 5). The Resplendent Quetzal enjoys the largest area of suitable habitat with 490,019 ha. The model predicts a long track along the central mountain ranges, spilling down the Atlantic coast towards the Caribbean through the densely forested regions in the middle of the country. For the Brook Frog, the model predicts a habitat distribution which is small, fragmented and limited to the lower to middle elevation slopes of the central cordillera (Fig. 5). The 49,699 ha of predicted suitable habitat is the smallest of the three species. For Geoffroy's Spider Monkey, 189,730 ha are mainly distributed in the lower elevation areas on the Pacific-side of the country. This is with the exception of a small area of low, humid forests in the north-eastern tip of the country and a long thin stretch along the Caribbean coast.

There were some areas of overlap between the suitable habitats of each of the species, the most prominent being areas suitable for both the Resplendent Quetzal and the Costa Rica Brook Frog on the medium elevation slopes in the centre of the country. However, there is a clear divide between the habitat suitability in the lower plains for Geoffroy's Spider Monkey and the suitability in the higher elevations for the Resplendent Quetzal and the Costa Rica Brook Frog; there was no overlap between the three. Nevertheless, there were some small patches on the Osa Peninsula suitable for both the Brook Frog and Geoffroy's Spider Monkey.

\subsection{Effectiveness of the PSA programme in storing carbon}

\subsubsection{Single-year analysis}

In 2013 alone, areas within the PSA programme were found to store more carbon than in eligible areas outside of the programme. On average, PSA areas stored 80 tonC ha ${ }^{-1}$ and eligible areas outside the programme stored 74 tonC $\mathrm{ha}^{-1}$. However in our regression analysis the difference was not significant (Fig. 6 and Table 6).

In contrast, areas within national parks stored a significantly larger amount of carbon on average than the two other policy scenarios, storing an additional 17 ton ha $^{-1}$ of carbon compared to PSA areas and 23 ton ha ${ }^{-1}$ more than in eligible forest outside of PSA and national park areas.
Table 6

Single-year model: Contrasts and associated p-values from Tukey Test.

\begin{tabular}{llll}
\hline Contrast & Estimate & SE & p-value \\
\hline PSA - Eligible & 5.56 & 2.83 & 0.121 \\
PSA - Park & -17.02 & 3.51 & $<0.00001$ \\
Eligible - Park & -22.58 & 3.63 & $<0.00001$ \\
\hline
\end{tabular}
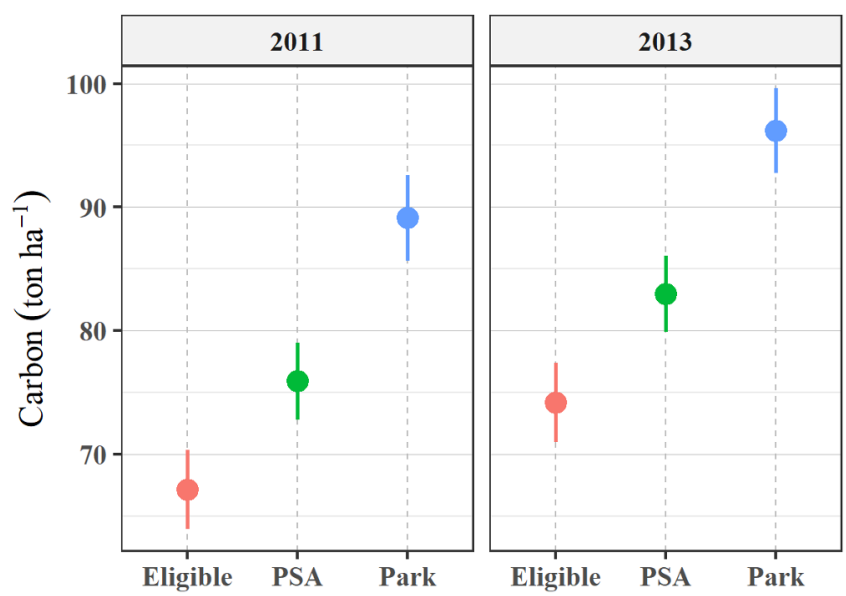

Fig. 7. Adjusted means for carbon storage (ton ha ${ }^{-1}$ ) in 2011 and 2013 per policy type. The points represent the mean carbon stored (ton ha ${ }^{-1}$ ), adjusted for the covariates road, slope and population, while the bars represent the $95 \%$ confidence intervals for each of the means. The model had an $\mathrm{R}^{2}$ of 0.41 .

Table 7

Time-series model: Contrasts and associated p-values from Tukey Test.

\begin{tabular}{llll}
\hline Contrast & Estimate & SE & p-value \\
\hline PSA - Eligible & 8.76 & 1.91 & $<0.0001$ \\
PSA - Park & -13.23 & 2.23 & $<0.00001$ \\
Eligible - Park & -21.99 & 2.35 & $<0.00001$ \\
$2013-2011$ & 7.06 & 1.54 & $<0.00001$ \\
\hline
\end{tabular}

\subsubsection{Short-term trend analysis}

A comparison of models Eqs. (3.4) and (3.5) showed the interaction term not to be significant (F-test $\mathrm{p}$-value $=0.42$ ). As a result, the effect of policy was assumed to be independent of the effect of year and model Eq. (3.4) was used to calculate adjusted means. Only PSA areas existing in both 2011 and 2013 were sampled for this model to enable an analysis over time. These areas were found to store a significantly larger amount of carbon in both years as compared with eligible areas outside the programme (Fig. 7 and Table 7). PSA areas on average stored an additional 9 tonC $\mathrm{ha}^{-1}$ in both 2011 and 2013.

National parks stored a significantly larger 13 tonC ha $^{-1}$ in both years as compared to PSA areas and 22 tonC $\mathrm{ha}^{-1}$ of additional carbon as compared to eligible areas.

\section{Discussion}

\subsection{ES model uncertainties}

PES practitioners require accurate spatial data to administer payments and assess the effectiveness of PES programmes (Börner et al., 2017). Ecosystem accounting aims to model ES with accurate outputs at high resolution and for large areas (UN et al., 2014). Both physical modelling and machine learning techniques can help achieve this (Willcock et al., 2018). Nevertheless, spatial models of ES come with uncertainties and require validation (Remme et al., 2014). Probabilistic 
ES measures under different scenarios have been proposed to quantify some of this uncertainty (Grêt-Regamey et al., 2013). Due to data constraints, we were unable to establish probabilistic ES measures and the accuracy of the spatial data is an unknown source of uncertainty in all three models. For example, land cover classification systems from remote sensing observations suffer from issues related to cloud cover, the imaging device on the satellite and are influenced by the specifics of the computer algorithms used to classify observations (Xie et al., 2008).

Considering carbon storage specifically, the restricted ability of remote sensing observations to estimate biomass, especially in tropical contexts, is well established (Gibbs et al., 2007) and was also apparent in this study. Spectral indices saturate at relatively low leaf densities in tropical countries whereas forests are structurally complex and have dense, closed canopies. This would explain the moderate $0.63 \mathrm{R}^{2}$ statistic produced by the random forest model for carbon storage. However, it is noteworthy that the carbon accounts produced by the Banco Central de Costa Rica for 2013 estimated - using the same data - 243 Mt of carbon for forested land in comparison to the $235 \mathrm{Mt}$ estimated in this study (BCCR, 2016).

A key limitation of using the RUSLE model to quantify soil erosion control in Costa Rica is that it was developed from plot data on agricultural lands in a more temperate climate in the U.S (Labrière et al., 2015). Cohen et al. (2005) report mixed results in cases where the estimated soil erosion has been assessed for accuracy using plot level data in tropical watersheds. The results in this study have been particularly affected by the steep gradients found in the country. The soil erosion control rates are fairly indistinguishable in the flat, low-land terrain but rise sharply in the more mountainous areas, leading to a highly skewed dataset. Still, Labrière et al. (2015) found that the RUSLE led to a similar gradient of soil erosion rates across different land uses in temperate and tropical areas, with almost identical erosion rates in forests. This suggests there is still a good applicability of the model to tropical forest. However, we did not have data to verify our model results, and we acknowledge that there remains uncertainty in our estimate, and that we cannot quantify the uncertainty in the model of this service.

Sampling bias is a prevalent issue in species distribution modelling (Beck et al., 2014). This effect was most evident in modelling the suitable habitat of Geoffroy's Spider Monkey. The small sample of 28 occurrences were heavily biased towards the more accessible areas on the coast. Maxent works well with small samples of data (Fourcade et al., 2014). However, in this case, the biases in the small number of occurrences has affected the validity of the results; the long thin stretch of habitat suitability along the Caribbean coast is almost certainly an artefact produced by this bias. Nevertheless, the distributions still shows a good consistency with large populations such as in Santa Rosa National Park in the northwest province of Guanacaste (Asensio et al., 2012). The modelled distributions of the two other species are also consistent with the reported distributions in the literature. The presence of the Resplendent Quetzal is captured accurately in migratory areas between 1000 and $1400 \mathrm{~m}$ (Powell and Bjork, 1994). The Brook Frog's habitat is consistent with large amphibian populations at intermediate peaks (Whitfield et al., 2016).

This consistency of the modelled distributions with species populations reported in the literature suggests the results can be used by administrators to target the suitable habitat of these iconic but threatened species. However, the extent to which the predicted habitats also include a wider pool of biodiversity is limited by the heterogeneity of the individual distributions which are quite specific to the species. For example, the model for the Costa Rica Brook Frog predicted a sparsely distributed suitable habitat that may be quite different to other amphibian species. The predicted suitable habitat for the Resplendent Quetzal is much larger but not all bird species, such as those native to the coasts, would share the same habitat. Nevertheless, the overlap of the modelled distributions with national parks and surrounding areas highlights the importance of targeting these surrounding areas for PSA contracts. In addition, as a cultural ES flow, the modelled distributions serve well as species-specific predictions that can assist administrators conserve the value of these species to tourism in the country.

\subsection{Regression analysis}

The single-year regression model (Eq. (3.3)) did not find that PSA areas stored a significantly larger amount of carbon. Our analysis also did not reveal any significant change in the effect of policy over time (0.42 p-value for the interaction in model Eq. (3.5)). However, the short-term trend analysis did show the PSA programme to have a significant effect on carbon storage in PSA areas enrolled in both 2011 and 2013. This suggests that areas which are committed long-term to the programme store a significantly larger amount of carbon as compared to unenrolled areas. This reflects similar findings in the literature. Sierra and Russman (2006) found that agricultural land use declined the longer payments were in effect, disappearing almost entirely by the fifth year. In a review of several sub-national studies of the PSA programme, Daniels et al. (2010) highlights this study among others as evidence for a long-term effect on forest expansion relative to a business-as-usual scenario. However, the limited temporal range in our study is a key limitation and limits any generalisation across the entire existence of the programme. In addition, both models displayed low predictive abilities with 0.42 and $0.41 \mathrm{R}^{2}$ statistics. The linear relationship assumed by the model between carbon storage and the predictor variables may not adequately reflect the true underlying phenomenon. Nonetheless, with some key anthropogenic influences accounted for, the significant difference in the amount of carbon stored in PSA versus unenrolled areas is a good indication that the PSA programme is responsible for a larger supply of carbon storage over time.

The discrepancy between the results of the single-year and shortterm trend analyses will have been in part because the long-term effect of the programme on forest regeneration is less present in the singleyear analysis. Newly enrolled areas containing recently abandoned land will have reduced the potential carbon storage in the sampling area. The sampling design may also have affected the results of both the single-year and the time-series analyses. PSA contract areas also contain agro-forestry, usually for coffee cultivation (Porras et al., 2013). This means the sampled area within PSA areas have a lower carbon storage potential as compared to the unenrolled, eligible areas consisting of primary forest, secondary forest and tree plantations. It was not possible to include eligible land under cultivation because there was no data available on the potential for agro-forestry. This means the additional carbon stored could be larger as compared to eligible areas.

Data constraints such as these contribute to the inherent difficulties in carrying out national-wide analyses of payment effectiveness. Other national studies of the PSA programme have tended to find little impact of the programme on deforestation rates as a proxy for ES supply. However, the study sampling designs were not found to consider factors such as pre-PES policy incentives or to distinguish between tree plantation harvests and the clearing of natural forest, possibly because of data limitations (Daniels et al., 2010). In more detailed, sub-national studies, where study design becomes more specific to local factors, a clearer effect of the PSA programme emerges. Specifically, the longterm effect on forest restoration (Daniels et al., 2010). The short-term trend analysis we conducted is consistent with these findings. Further research should focus on extending the temporal range of the analysis and validating whether the contract areas in 2011 and 2013 were also enrolled in the programme in other years.

\subsection{Relevancy of the results to PES administrators}

Spatial quantification of ES allows PES practitioners to directly monitor the efficiency of a programme (Börner et al., 2017). The additionality of a programme is a core measure of PES effectiveness. This is the additional amount of ES supplied as compared to a baseline with no payments (Wunder, 2008). In this case, the spatial distributions of 
carbon storage enabled an analysis of the effect of the programme on carbon storage using linear regression. This showed that the programme was responsible for an additional 9 tonC ha $^{-1}$ in PSA areas enrolled in both 2011 and 2013 versus unenrolled areas, supporting a direct quantification of additionality. However, the moderate $\mathrm{R}^{2}$ statistics of the models means there remains a degree of uncertainty around these figures and they should not be solely relied upon as a measure of effectiveness. It is also important to consider a longer time horizon in the analysis, preferably stretching back to the programme's inception. Nevertheless, the ES-based measures of additionality presented in this study show that a measure more relevant to the concept is possible where before studies have mostly relied on deforestation as a proxy (Börner et al., 2017).

In Costa Rica, however, additionality is not a requirement of the PSA programme (Sierra and Russman, 2006). On the other hand, the programme does seek to target areas with the highest provision of ecosystem services, prioritising private land inside biological corridors, protected areas and important watersheds (Barton et al., 2009). This is also true of many other PES programmes; practitioners need to target areas with the highest service provision and those most under threat (Wunder et al., 2008). Although administrators must still consider the uncertainties in the underlying models, the modelling approach applied in our paper enables practitioners to identify high-value areas with a greater degree of accuracy and to spatially examine ES flows in relation to threats such as roads and population centres. This also improves the information currently available to administrators and, in the long-run, should help to boost the additionality of a programme (Börner et al., 2017).

Monitoring the spatial distributions of ES over time can also assist practitioners to assess compliance and administrate payments. The conditionality of ES supply is a defining feature of PES (Wunder, 2015). Nonetheless, there remain significant uncertainties in the modelling techniques used to map ES. This could affect the accuracy of these assessments. Moreover, if payments were administered based on supply, inaccuracies in the assessment could lead to unfair compensation and reduce the appeal of the programme. ES value can also vary depending on the scale of measurement (Hein et al., 2006). For example, the benefits of soil erosion control in one watershed may be greater than another if measured at the local scale. In addition, land managers may face different ecosystem management and/or opportunity costs, which may also be relevant in determining the monetary compensation in a PES programme (Börner et al., 2017). Nonetheless, the ES maps have the potential to reduce the administrative burden in highlighting areas with significant changes in ES supply, allowing administrators to prioritise areas for further investigation.

Ultimately, PES practitioners want to conserve the maximum amount of ecosystem value. To do this, ES need to be valued to understand the benefits to society versus the costs of securing ES supply (Tacconi, 2012). The spatial quantification of ES can enable this comparison through ES valuation. A specific consequence of the SEEA EA approach is a greater opportunity for practitioners to understand the market efficiency of a programme, although in many cases it is difficult to establish an exchange value for ES, particularly biodiversity and cultural services (UN et al., 2014). In these cases, alternative methods of valuation may be more appropriate such as those that capture the consumer surplus: a welfare economics approach. Muradian et al. (2010) have called for an even broader conceptualisation of PES value that also captures local cultural settings. As an alternative valuation approach, the Inter-governmental Panel on Biodiversity and Ecosystem Services (IPBES) has developed an ecosystem assessment framework to capture both welfare and non-monetary values (Díaz et al., 2018). Nonetheless, the spatial approach taken by the SEEA EA is still very relevant to measuring ES value using these alternative methods in generating the biophysical quantities. Moreover, in the cases where exchange values for ES can be established, these can be used to make payments more market-efficient. This can help create a more cost- effective programme, allow more landowners to participate and result in a greater supply of ES.

\section{Conclusion}

This study has shown that spatially quantifying ES for the purposes of examining PES effectiveness is feasible. We modelled three ES relevant to the PSA programme in Costa Rica: carbon storage, soil erosion control and the habitat suitability of three culturally iconic but threatened species. We found the modelled distributions to be consistent with other findings in the literature. These spatial ES quantities can allow administrators to examine in greater detail whether the PSA programme is targeting the most high-value areas and prioritise contract areas that may not be compliant. It also enabled an analysis of the additionality of the PSA programme for carbon storage which revealed PSA contract areas enrolled in both 2011 and 2013 to store a significantly larger amount of carbon as compared to unenrolled but eligible areas. An analysis of all PSA contract areas in 2013 alone did not reveal a significant difference. This suggests the programme has a larger effect on areas enrolled over time. Still, uncertainties remain in the spatial models and the underlying data used to quantify ES as well as the regression models used to quantify the additionality of the programme. Nevertheless, overall, spatial quantification enables more detailed and relevant measures of PES effectiveness which, in turn, can assist practitioners to further boost the social-efficiency of a payment scheme.

\section{Acknowledgements}

The first author would like to thank Luis Rivera for some initial discussions regarding the research and all the staff at the Instituto de Investigación y Servicios Forestales for hosting him while in Costa Rica. The authors would also like to thank two anonymous reviewers for helping us improve on a previous version of the manuscript.

\section{Funding}

This research did not receive any specific grant from funding agencies in the public, commercial, or not-for-profit sectors.

\section{Appendix A. Supplementary data}

Supplementary data to this article can be found online at https:// doi.org/10.1016/j.ecolind.2019.105766.

\section{References}

ADUU, 2015. Generando una serie de tiempo histórica consistente de datos de cambios de uso de la tierra para el desarrollo de un nivel de referencia de Costa Rica para REDD +. Technical Report. San José, Costa Rica.

Angima, S.D., Stott, D.E., O’Neill, M.K., Ong, C.K., Weesies, G.A., 2003. Soil erosion prediction using RUSLE for central Kenyan highland conditions. Agric. Ecosyst. Environ. 97, 295-308. https://doi.org/10.1016/S0167-8809(03)00011-2.

Asensio, N., Schaffner, C.M., Aureli, F., 2012. Variability in core areas of spider monkeys (Ateles geoffroyi) in a tropical dry forest in Costa Rica. Primates 53, 147-156. https://doi.org/10.1007/s10329-011-0288-9.

Baccini, A., Friedl, M.A., Woodcock, C.E., Warbington, R., 2004. Forest biomass estimation over regional scales using multisource data. Geophys. Res. Lett. 31, 2-5. https:// doi.org/10.1029/2004GL019782.

Baccini, A., Laporte, N., Goetz, S.J., Sun, M., Dong, H., 2008. A first map of tropical Africa's above-ground biomass derived from satellite imagery. Environ. Res. Lett. 3, 045011. https://doi.org/10.1088/1748-9326/3/4/045011.

Barton, D.N., Faith, D.P., Rusch, G.M., Acevedo, H., Paniagua, L., Castro, M., 2009. Environmental service payments: evaluating biodiversity conservation trade-offs and cost-efficiency in the Osa Conservation Area, Costa Rica. J. Environ. Manage. 90, 901-911. https://doi.org/10.1016/j.jenvman.2008.02.010.

Batista, P.V.G., Silva, M.L.N., Silva, B.P.C., Curi, N., Bueno, I.T., Acérbi Júnior, F.W., Davies, J., Quinton, J., 2017. Modelling spatially distributed soil losses and sediment yield in the upper Grande River Basin - Brazil. Catena 157, 139-150. https://doi.org/ 10.1016/j.catena.2017.05.025.

BCCR, 2016. Forest Accounts. San José, Costa Rica. 
Beck, J., Böller, M., Erhardt, A., Schwanghart, W., 2014. Spatial bias in the GBIF database and its effect on modeling species' geographic distributions. Ecol. Inform. 19, 10-15. https://doi.org/10.1016/j.ecoinf.2013.11.002.

Bell, K.E., Donnelly, M.A., 2006. Influence of forest fragmentation on community structure of frogs and lizards in northeastern Costa Rica. Conserv. Biol. 20, 1750-1760. https://doi.org/10.1111/j.1523-1739.2006.00522.x.

Börner, J., Baylis, K., Corbera, E., Ezzine-de-Blas, D., Honey-Rosés, J., Persson, U.M., Wunder, S., 2017. The effectiveness of payments for environmental services. World Dev. 96, 359-374. https://doi.org/10.1016/j.worlddev.2017.03.020.

Boza, M., 1993. Conservation in action: past, present, and future of the national park system of Costa Rica. Conserv. Biol. 7, 239-247.

Breiman, L., 2001. Random forests. Mach. Learn. 45, 5-32. https://doi.org/10.1023/ A:1010933404324.

Bullock, J.M., Aronson, J., Newton, A.C., Pywell, R.F., Rey-Benayas, J.M., 2011. Restoration of ecosystem services and biodiversity: conflicts and opportunities. Trends Ecol. Evol. 26, 541-549. https://doi.org/10.1016/J.TREE.2011.06.011.

Caro, T., Engilis, A., Fitzherbert, E., Gardner, T., 2004. Preliminary assessment of the flagship species concept at a small scale. Anim. Conserv. 7, 63-70. https://doi.org/ 10.1017/S136794300300115X

Chamberlain, S., 2017. rgbif: Interface to the Global 'Biodiversity' Information Facility 'API'.

Cohen, M.J., Shepherd, K.D., Walsh, M.G., 2005. Empirical reformulation of the universal soil loss equation for erosion risk assessment in a tropical watershed. Geoderma 124, 235-252. https://doi.org/10.1016/j.geoderma.2004.05.003.

Daniels, A.E., Bagstad, K., Esposito, V., Moulaert, A., Rodriguez, C.M., 2010. Understanding the impacts of Costa Rica's PES: Are we asking the right questions? Ecol. Econ. 69, 2116-2126. https://doi.org/10.1016/j.ecolecon.2010.06.011.

Defries, R.S., Rudel, T., Uriarte, M., Hansen, M., 2010. Deforestation driven by urban population growth and agricultural trade in the twenty-first century. Nat. Geosci. 3, 178-181. https://doi.org/10.1038/ngeo756.

Díaz, S., Pascual, U., Stenseke, M., Martín-López, B., Watson, R.T., Molnár, Z., Hill, R., Chan, K.M.A., Baste, I.A., Brauman, K.A., Polasky, S., Church, A., Lonsdale, M. Larigauderie, A., Leadley, P.W., van Oudenhoven, A.P.E., van der Plaat, F., Schröter, M., Lavorel, S., Aumeeruddy-Thomas, Y., Bukvareva, E., Davies, K., Demissew, S. Erpul, G., Failler, P., Guerra, C.A., Hewitt, C.L., Keune, H., Lindley, S., Shirayama, Y., 2018. Assessing nature's contributions to people. Science (80-) 359, 270-272.

Dimiceli, C., Carroll, M., Sohlberg, R., Kim, D.H., Kelly, M., Townshend, J.R.G., 2015. MOD44B MODIS/Terra Vegetation Continuous Fields Yearly L3 Global 250m SIN Grid V006 [Data set]. NASA EOSDIS L. Process. DAAC.

Engel, S., Pagiola, S., Wunder, S., 2008. Designing payments for environmental services in theory and practice: an overview of the issues. Ecol. Econ. 65, 663-674. https://doi. org/10.1016/j.ecolecon.2008.03.011.

FAO, 2012. Harmonized World Soil Database (Version 1.2). IIASA, Rome, Italy/ Laxenburg, Austria.

Ferraro, P.J., Hanauer, M.M., Sims, K.R.E., 2011. Conditions associated with protected area success in conservation and poverty reduction. Proc. Natl. Acad. Sci. U.S.A. 108, 13913-13918. https://doi.org/10.1073/pnas.1011529108.

Fick, S.E., Hijmans, R., 2017. Worldclim 2: New 1-km spatial resolution climate surfaces for global land areas. Int. J. Climatol. 37, 4302-4315.

FONAFIFO, 2018. Dirección de Servicios Ambientales. San José, Costa Rica.

Fourcade, Y., Engler, J.O., Rödder, D., Secondi, J., 2014. Mapping species distributions with MAXENT using a geographically biased sample of presence data: a performance assessment of methods for correcting sampling bias. PLoS One 9, 1-13. https://doi. org/10.1371/journal.pone.0097122.

Garcia-Rodriguez, A., Chaves, G., Benavides-Varela, C., Puschendorf, R., 2012. Where are the survivors? Tracking relictual populations of endangered frogs in Costa Rica. Divers. Distrib. 18, 204-212. https://doi.org/10.1111/j.1472-4642.2011.00862.x.

GBIF, 2017. Global Biodiversity Information Facility [WWW Document]. (accessed 2.1.18). https://www.gbif.org/.

Gibbs, H.K., Brown, S., Niles, J.O., Foley, J.A., 2007. Monitoring and estimating tropical forest carbon stocks: making REDD a reality. Environ. Res. Lett. 2, 045023. https:// doi.org/10.1088/1748-9326/2/4/045023.

Graham, K.E., Bulloch, M.J., Lewis, T.R., 2013. Foraging behaviour of three primate species in a Costa Rican coastal lowland tropical wet forest. Biodivers. J. 4, 327-334.

Grêt-Regamey, A., Brunner, S.H., Altwegg, J., Bebi, P., 2013. Facing uncertainty in ecosystem services-based resource management. J. Environ. Manage. 127, S145-S154. https://doi.org/10.1016/j.jenvman.2012.07.028.

Guerry, A.D., Polasky, S., Lubchenco, J., Chaplin-Kramer, R., Daily, G.C., Griffin, R., Ruckelshaus, M., Bateman, I.J., Duraiappah, A., Elmqvist, T., Feldman, M.W., Folke, C., Hoekstra, J., Kareiva, P.M., Keeler, B.L., Li, S., McKenzie, E., Ouyang, Z., Reyers, B., Ricketts, T.H., Rockström, J., Tallis, H., Vira, B., 2015. Natural capital and ecosystem services informing decisions: from promise to practice. Proc. Natl. Acad. Sci. U.S.A. 112, 7348-7355. https://doi.org/10.1073/pnas.1503751112.

Hearne, R.R., Salinas, Z.M., 2002. The use of choice experiments in the analysis of tourist preferences for ecotourism development in Costa Rica. J. Environ. Manage. 65, 153-163. https://doi.org/10.1006/jema.2001.0541.

Hein, L., Obst, C., Edens, B., Remme, R.P., 2015. Progress and challenges in the development of ecosystem accounting as a tool to analyse ecosystem capital. Curr. Opin. Environ. Sustain. 14, 86-92. https://doi.org/10.1016/j.cosust.2015.04.002.

Hein, L., van Koppen, K., de Groot, R.S., van Ierland, E.C., 2006. Spatial scales, stakeholders and the valuation of ecosystem services. Ecol. Econ. 57, 209-228. https://doi. org/10.1016/j.ecolecon.2005.04.005.

Herrera, W., 2016. The physical environment. In: Kappelle, M. (Ed.), Costa Rican Ecosystems. University of Chicago Press, Chicago.

Houghton, R.A., Butman, D., Bunn, A.G., Krankina, O.N., Schlesinger, P., Stone, T.A., 2007. Mapping Russian forest biomass with data from satellites and forest inventories. Environ. Res. Lett. 2, 045032. https://doi.org/10.1088/1748-9326/2/4/ 045032

Hoyos, N., 2005. Spatial modeling of soil erosion potential in a tropical watershed of the Colombian Andes. Catena 63, 85-108. https://doi.org/10.1016/j.catena.2005.05. 012.

IUCN, 2015. The IUCN Red List Of Threatened Species. Gland, Switzerland.

Jin, S., Sader, S.A., 2005. Comparison of time series tasseled cap wetness and the normalized difference moisture index in detecting forest disturbances. Remote Sens. Environ. 94, 364-372. https://doi.org/10.1016/j.rse.2004.10.012.

Kappelle, M., 2016. Costa Rica's ecosystems: setting the stage. In: Kappelle, M. (Ed.), Costa Rican Ecosystems. University of Chicago Press, Chicago.

Kuhn, M., 2008. Building predictive models in R using the caret package. J. Stat. Softw. 1. https://doi.org/10.18637/jss.v028.i05.

Kuhn, M., Johnson, K., 2013. In: Applied Predictive Modeling. Springer, New York, New York, NY. https://doi.org/10.1007/978-1-4614-6849-3.

Labrière, N., Locatelli, B., Laumonier, Y., Freycon, V., Bernoux, M., 2015. Soil erosion in the humid tropics: a systematic quantitative review. Agric. Ecosyst. Environ. 203, 127-139. https://doi.org/10.1016/j.agee.2015.01.027.

Laurance, W.F., Goosem, M., Laurance, S.G.W., 2009. Impacts of roads and linear clearings on tropical forests. Trends Ecol. Evol. 24, 659-669. https://doi.org/10.1016/j. tree.2009.06.009.

Locatelli, B., Imbach, P., Wunder, S., 2013. Synergies and trade-offs between ecosystem services in Costa Rica. Environ. Conserv. 41, 27-36. https://doi.org/10.1017 S0376892913000234.

Millward, A.A., Mersey, J.E., 1999. Adapting the RUSLE to model soil erosion potential in a mountainous tropical watershed. Catena 38, 109-129. https://doi.org/10.1016/ S0341-8162(99)00067-3.

Muradian, R., Corbera, E., Pascual, U., Kosoy, N., May, P.H., 2010. Reconciling theory and practice: an alternative conceptual framework for understanding payments for environmental services. Ecol. Econ. 69, 1202-1208. https://doi.org/10.1016/j. ecolecon.2009.11.006.

Pagiola, S., 2008. Payments for environmental services in Costa Rica. Ecol. Econ. 65, 712-724. https://doi.org/10.1016/j.ecolecon.2007.07.033.

Peterson, R.T., Chalif, E.L., 1973. A field guide to Mexican birds. Houghton Mifflin Co., Massachusetts.

Phillips, S.J., Anderson, R.P., Dudík, M., Schapire, R.E., Blair, M.E., 2017. Opening the black box: an open-source release of Maxent. Ecography (Cop.) 40, 887-893. https:// doi.org/10.1111/ecog.03049.

Phillips, S.J., Anderson, R.P., Schapire, R.E., 2006. Maximum entropy modeling of species geographic distributions. Ecol. Model. 190, 231-259. https://doi.org/10.1016/j. ecolmodel.2005.03.026.

Phillips, S.J., Dudik, M., Elith, J., Graham, C.H., Leathwick, J., Ferrier, S., Applications, S.E., Jan, N., Phillips, S.J., Dud, M., Elith, J., Graham, C.H., Lehmann, A., Leathwick, J., Ferrier, S., 2009. Sample selection bias and presence-only distribution models: implications for background and pseudo-absence data stable. Ecol. Appl. 19, 181-197.

Porras, I., Barton, D., Miranda, M., Chacón-Cascante, A., 2013. Learning from 20 years of Payments for Ecosystem Services in Costa Rica. London.

Powell, G.V.N., Bjork, R.D., 1994. Implications of altitudinal migration for conservation strategies to protect tropical biodiversity: a case study of the Resplendent Quetzal Pharomacrus mocinno at Monteverde, Costa Rica. Bird Conserv. Int. 4, 161-174. https://doi.org/10.1017/S0959270900002744.

Programa REDD/CCAD-GIZ-SINAC, 2015. Inventario Nacional Forestal de Costa Rica 2014-2015. San José, Costa Rica.

Rands, M.R.W., Adams, W.M., Bennun, L., Butchart, S.H.M., Clements, A., Coomes, D., Entwistle, A., Hodge, I., Kapos, V., Scharlemann, J.P.W., Sutherland, W.J., Vira, B., 2010. Biodiversity conservation: challenges beyond 2010. Science (80-) 329, 1298. https://doi.org/10.1126/science.1189138. LP-1303.

Remme, R.P., Schröter, M., Hein, L., 2014. Developing spatial biophysical accounting for multiple ecosystem services. Ecosyst. Serv. 10, 6-18. https://doi.org/10.1016/j ecoser.2014.07.006.

Renard, K.G., Foster, G.R., Weesies, G., McCool, D.K., Yoder, D.C., 1997. Predicting Soil Erosion by Water: A Guide to Conservation Planning With the Revised. Universal Soil Loss Equation (RUSLE)

Robalino, J.A., Pfaff, A., 2013. Ecopayments and deforestation in Costa Rica: a nationwide analysis of PSA's initial years. Land Econ. 89, 432-448. https://doi.org/10. 1353/lde.2013.0027.

Rubin, B.D., Hyman, G.G., 2000. The extent and economic impacts of soil erosion in Costa Rica. In: Hall, C.A. (Ed.), Quantifying Sustainable Development-The Future of Tropical Economics. Academic Press, San Diego, Ca, pp. 449-471.

Saatchi, S., Houghton, R.A., Dos Santos Alvalá, R.C., Soares, J.V., Yu, Y., 2007. Distribution of aboveground live biomass in the Amazon basin. Glob. Chang. Biol. 13, 816-837. https://doi.org/10.1111/j.1365-2486.2007.01323.x.

Schaaf, C., Wang, Z., 2015. MCD43A4 MODIS/Terra + Aqua BRDF/Albedo Nadir BRDF Adjusted Ref Daily L3 Global - 500m V006 [Data set]. NASA EOSDIS L. Process. DAAC.

Schaaf, C.B., Gao, F., Strahler, A.H., Lucht, W., Li, X., Tsang, T., Strugnell, N.C., Zhang, X., Jin, Y., Muller, J.P., Lewis, P., Barnsley, M., Hobson, P., Disney, M., Roberts, G., Dunderdale, M., Doll, C., D’Entremont, R.P., Hu, B., Liang, S., Privette, J.L., Roy, D., 2002. First operational BRDF, albedo nadir reflectance products from MODIS. Remote Sens. Environ. 83, 135-148. https://doi.org/10.1016/S0034-4257(02) 00091-3.

Sierra, R., Russman, E., 2006. On the efficiency of environmental service payments: a forest conservation assessment in the Osa Peninsula, Costa Rica. Ecol. Econ. 59, 131-141. https://doi.org/10.1016/j.ecolecon.2005. 10.010.

Steffen, W., Richardson, K., Rockström, J., Cornell, S.E., Fetzer, I., Bennett, E.M., Biggs, 
R., Carpenter, S.R., de Vries, W., de Wit, C.A., Folke, C., Gerten, D., Heinke, J., Mace, G.M., Persson, L.M., Ramanathan, V., Reyers, B., Sörlin, S., 2015. Planetary boundaries: guiding human development on a changing planet. Science (80-) 347.

Sumarga, E., Hein, L., 2014. Mapping ecosystem services for land use planning, the case of Central Kalimantan. Environ. Manage. 54, 84-97. https://doi.org/10.1007/ s00267-014-0282-2.

Tacconi, L., 2012. Redefining payments for environmental services. Ecol. Econ. 73, 29-36. https://doi.org/10.1016/j.ecolecon.2011.09.028.

TRMM, 2015. Daily TRMM and Other Satellites Precipitation Product (3B42 V6 derived) [Data set]. Goddard Sp. Flight Cent. Distrib. Act. Arch. Cent. (GSFC DAAC).

UN, 2017. SEEA Experimental Ecosystem Accounting: Technical Recommendations Consultation Draft. New York, USA.

UN, EU, FAO, IMF, OECD, WorldBank, 2014. System of Environmental-Economic Accounting 2012: Experimental Ecosystem Accounting. New York, USA.

USGS, 2006. Digital Elevation - Shuttle Radar Topography Mission (SRTM), Center for Earth Resource Observation and Science (EROS). Sioux Falls, USA.

Wheelwright, N.T., 2016. Fruits and the ecology of resplendent quetzals. Am. Ornithol. Soc. 100, 286-301.

Whitfield, S.M., Lips, K.R., Donnelly, M.A., 2016. Amphibian decline and conservation in central America. Copeia 104, 351-379. https://doi.org/10.1643/CH-15-300.
Willcock, S., Martínez-López, J., Hooftman, D.A.P., Bagstad, K.J., Balbi, S., Marzo, A., Prato, C., Sciandrello, S., Signorello, G., Voigt, B., Villa, F., Bullock, J.M., Athanasiadis, I.N., 2018. Machine learning for ecosystem services. Ecosyst. Serv. 33, 165-174. https://doi.org/10.1016/j.ecoser.2018.04.004.

Wright, M.N., Ziegler, A., 2017. ranger: a fast implementation of random forests for high dimensional data in C + + and R. J. Stat. Softw. 77, 1-17. https://doi.org/10.18637/ jss.v077.i01.

Wunder, S., 2015. Revisiting the concept of payments for environmental services. Ecol. Econ. 117, 234-243. https://doi.org/10.1016/j.ecolecon.2014.08.016.

Wunder, S., 2008. Payments for environmental services and the poor: concepts and preliminary evidence. Environ. Dev. Econ. 13, 279-297. https://doi.org/10.1017/ S1355770X08004282.

Wunder, S., Engel, S., Pagiola, S., 2008. Taking stock: a comparative analysis of payments for environmental services programs in developed and developing countries. Ecol. Econ. 65, 834-852. https://doi.org/10.1016/j.ecolecon.2008.03.010.

Xie, Y., Sha, Z., Yu, M., 2008. Remote sensing imagery in vegetation mapping: a review. J. Plant Ecol. 1, 9-23. https://doi.org/10.1093/jpe/rtm005.

Yin, G., Zhang, Y., Sun, Y., Wang, T., Zeng, Z., Piao, S., 2015. MODIS based estimation of forest aboveground biomass in China. PLoS One 10,1-13. https://doi.org/10.1371 journal.pone.0130143. 